\title{
Essay Review: A Critique of some Recent Textbooks on Women in American History
}

\section{Siri Nylander}

Telemark Regional College

A certain minimum of knowledge about American women, past and present, must by now be considered an indispensable part of the study of American civilization.

Even the most cursory introduction to the American scene in the nineteen sixties and seventies can hardly avoid at least a passing mention of the new women's movement as one of the many social movements of the period. If nothing has been said of women in the past, such a reference will remain isolated and nearly meaningless. My search for information on women in American history was originally inspired by the wish to find the most necessary historical background in a simple, yet coherent form. For this reason I have concentrated on booklength studies that cover the whole period from colonial times onwards. Gerda Lerner's The Woman in American History (1971), Edith Hoshino Altbach's Women in America (1974), and Mary P. Ryan's Womanhood in America: From Colonial Times to the Present (1975) all fall within this category, at the same time suggesting the variety of attitudes and approaches to be found among American historians with regard to this subject ${ }^{1}$

What began as a practical search for facts, has, however, turned into something much more complicated as new terms and principles emerged and seemed to demand clarification. Before going on to a more detailed consideration of the thrce books, I shall therefore make some general remarks about the relationship between Women's Studies and American Studies, and discuss briefly the concept of women's history with special reference to the American situation.

A veritable explosion of academic interest in the various aspects of the lives of women has followed in the wake of the New Feminist or Women's Liberation Movement, which emerged in the US towards the end of the sixties. This interest is most easily apparent 
in the rapid growth of course offerings, commonly grouped together under the label "Women's Studies" regardless of departmental affiliation or the sex of the teachers and students involved. Such courses have sprouted from a mere handful in 1969, to an estimated 600 in 1971,1500 in 1972-73, 4658 (!) in 1974. In the same period there has been a considerable increase in the publication of scholarly work on women: new books and articles, reprints $\mathbf{f}$ halfforgotten older works, bibliographies, and, last but not least, several new academic journals exclusively devoted to Women's Studies. ${ }^{2}$

It is difficult to get a clear picture of the exact relationship between this developing field of Women's Studies and the somewhat more established American Studies. Institutional arrangements as well as the identification of individual scholars with one or the other field or special subject vary widely. In its broadest conception Women's Studies will cross national boundaries and be concerned with the situation of women in all cultures. It may also tend to be even more interdisciplinary that American Studies in including such disciplines as biology and psychology. In practice, however, it seems that a very large portion of the work done in Women's Studies in the US can in some way be encompassed within American Studies. While much of this work may also tell us something about the general problems of women regardless of nationality, the materials and the practical results largely concern American women in particular and can hardly be understood except in relation to American society and its peculiarities.

In 1972 the American Studies Association passed a number of resolutions concerning women and academic work, including the recommendation of "expanding course materials in present American Studies courses to include units and projects on the American woman," encouragement of students of both sexes to "focus upon the topic of women in American life through dissertations, theses, and seminars," "addition of courses in Women's Studies where they do not now exist," and the endorsement of "the principle that Women's Studies be part of American Studies just as Black Studies, Urban Studies, and Ethnic Studies may be covered by the umbrella of American Studies, i.e. without thereby insisting that only the American dimension of the subject is pertinent."3

Undoubtedly something remains to be done before these goals are fully realized, but much has already been achieved. The 1975 
ASA Conference included substantial elements of Women's Studies, and a recent issue of American Quarterly, particularly devoted to a broad overview of the whole field of American Studies in the US, contained a number of references to Women's Studies. ${ }^{4}$

American Studies abroad neither can nor should be an exact copy of American Studies in America. For obvious reasons the work done abroad will usually have a different starting-point-that of the outsider observing a foreign culture - and will perhaps more often be concerned with cross-cultural influences or comparisons. In principle there can, however, be no particular reason why Women's Studies should not also be an important concern of American Studies abroad. (After all, women, the subject of the field, constitute the majority of the US population, or, to be exact, 51.2 per cent in 1975.5 ) In practice there seem to be certain difficulties. For one thing, the introductory textbook surveys of American culture do not usually pay great attention to women and their situation, which means that future scholars are not encouraged to think of this field as a natural concern of American Studies. ${ }^{6}$ Moreover, it is not always easy, even for those who are interested, to find supplementary information, particularly on women in American history. Such difficulties seem to be greater abroad, though they may also to a certain extent be seen as a reflection of the situation in the US.

As recently as 1974 Roberta Balstad Miller could say, in her article "Women and American History," that although "perceptive and well-researched studies of women" had been produced in the past, such work was never really considered part of the mainstream of historical scholarship, and was consequently"too often ignored." "7 Thus, even knowledge about American women that has been available for a long time, has not been included in most general histories, just as the history of women has not Seen sufficiently integrated into the history of mankind.

Despite the efforts of such a pioneer as Mary Beard, whose work has been "largely ignored" until recently, ${ }^{8}$ women's history must be regarded as a relatively new field, as yet only slightly developed. For instance, Miller also complains about "the paucity of the literature on many aspects" and maintains that "women's history does not have major synthetic works as do other fields in American history." " Clearly, we must turn to more specialized studies for information on American women of the past, but such studies are often hard to come by abroad, though there may be signs of 
improvement as our research libraries begin to see their obligation to provide literature on hitherto neglected topics. ${ }^{10}$ Future developments in the field of history will, of course, also depend on the extent to which Women's Studies in general gains ground in our institutions of higher learning.

The major obligation to discuss and develop the concept of women's history as well as problems of method, rests with the special departments of history. It is not my intention to advocate the introduction of women's history as a separate discipline within American Studies in Scandinavia, at least as far as teaching is concerned, nor necessarily to recommend a substantially greater emphasis on history as part of American Studies. But if we wish to help redress the previous imbalance, special efforts are unavoidable at first, including the attempt to cross departmental barriers and try to learn what is going on in the disciplines which provide much of the material and inspiration for American Studies.

What, then, is women's history, why and how has it developed? However briefly one tries to answer such questions, it is customary, and still seems necessary, to start with a comment on the lack of information about women and the possible reasons for this deficiency. Mary Beard may be right in feeling that male historians have tended to overlook women because they were women, though her claim that women have been an active "force in making all the history that has been made" sounds somewhat exaggerated. ${ }^{11}$ Other historians have pointed to the traditional definitions of history, which include "only those aspects of human experience in which men are active." 12 The two explanations do not cancel each other out, but meet if we consider the concept of power as does Gerda Lerner in her discussion of "New Approaches to the Study of Women in American History" :

As long as historians held to the traditional view that only the transmission and exercise of power were worthy of their interest, women were of necessity ignored. There was little room in political, diplomatic, and military history for American women, who were longer than any other single group in the population, outside the power structure. At best their relationship to power was implicit and peripheral and could easily be passed over as insignificant. ${ }^{13}$

No wonder perhaps that historians, to the extent that they have included women at all, have until recently paid greatest attention to that one period in the past when women seemed to make a grab for power in the ordinary political sense through the demand for suffrage. Most of the brief references to women in general 
histories concern the gaining of the vote, and a substantial proportion of the special studies, which could be labeled women's history, concentrates on organized movements, particularly in connection with the suffrage campaign. In the US an additional factor may have been the tendency of American historians to conclude, as Henry Steele Commager has pointed out, "that the significance of history was to be found in the struggle for freedom." 14

Certainly, women's struggle for freedom should be dealt with, regardless of whether one agrees with its methods and definitions of goals, but it is not identical with the history of American women. Nor, by the way, is the struggle for suffrage identical with the history of American feminism. ${ }^{15}$ In principle, the history of women in America must be said to embrace all groups of women, just as the term women's history may be used to designate collectively all work dealing with the activities of women in the past and problems of special relevance to women in earlier times. ${ }^{16}$ There is, however, no unanimous agreement on what should be the primary concerns of the field .In practice, it seems that the old women's movement has received rather more than a fair share of the attention compared with other aspects of women's history. ${ }^{17}$ My decision not to deal here with studies devoted exclusively to this one aspect, stems not from a lack of interest, but from a wish to complete the picture by drawing attention to other aspects of the history of women in America.

This wish coincides with what seems to be a general trend in history, away from the heavy concentration on traditional power and the groups or individuals who held it, tawards a greater concern with the anonymous, the previously invisible. Indeed, the recent growth of interest in women's history is often seen as a result of the increased concern with social history. Clearly, the same methods and types of sources are generally used. Nevertheless, women's history is not strictly limited or clearly defined once and for all. Certain approaches may turn out to be more fruitful than others, especially if a combination of scholarly and political concerns is desired, but on the whole William $\mathrm{H}$. Chafe seems to give a lair summary of the situation: "There is no single, effective approach to the study of women's history, of course. The subject is as elusive as it is large, and it is fraught with methodological and conceptual difficulties." 18 Such difficulties may be expected to mar most work in this field for some time yet, as new approaches are tried out, perhaps for the first time. 
Chafe's own book, The American Woman: Her Changing Social, Economic, and Political Roles, 1920-1970, is a valiant attempt at coping with some of these problems, and assembles much useful information. The same might be said of Roger Thompson's Women in Stuart England and America, which is particularly interesting in its concern with comparisons, not only between England and America, but between different regions. Thompson's study seems to prove definitely that women were indeed better off in the colonies than in the old country, at the same time suggesting that not all the early gains were maintained. ${ }^{19} \mathrm{He}$ does, however, not go as far as Joan Hoff Wilson, who in her paper "Women As a Declining Force in American History" advances the view that "in certain respects women have declined rather than risen as a vital force in American life since the colonial period." 20 Naturally, new knowledge and controversial conclusions are most likely to appear in such special studies as these, which must be indispensable to the scholar, but the more comprehensive, and hence less specialized, surveys are equally necessary for general purposes of study. The remainder of this essay will therefore be devoted to a critique of the three books mentioned initially, with special emphasis on definitions and intentions, aspects included, manner of presentation and types of sources used. It is not my intention to provide a complete summary of the factual information contained in each book, but rather to guide potential readers towards the particular book which might suit their purposes best. ${ }^{21}$

Gerda Lerner in The Woman in American History (1971) takes her cue from Mary Beard's positive view of women as an important force in history, stating confidently: "Women have a history worth knowing" (p. 5). She wishes to describe "women's social, marital, economic, and legal-political status" at different points in American history, "examine how and why it has changed and analyze the significance of these changes." She will include the contributions of outstanding women, but insists that she is

equally concerned with tracing the ways in which ordinary women have contributed to the American quest for freedom, security, and abundance. If history has heroes, it also has heroines. More significant than isolated individuals, however, are the forces exerted by groups of people having similar concerns and needs. One such force, a significant and generally constructive one, has been the force of women in America. (p. 6)

These differentconcerns do not, however, receive equal weight in the actual text. Lerner does give brief sketches of the economic 
and social background of each period, includes some information on the lives of ordinary women as well as on prevailing attitudes, and touches on the various functions of women, but her over-all emphasis is placed rather heavily on individual, outstanding women. In addition to mentioning numerous names in passing, she provides thirty-four short biographies (from half a page to four pages in length). This is, of course, only a small selection of the many exceptional women about whom some information is available, ${ }^{22}$ but in such a brief history it seems entirely out of proportion, leaving little room for the anonymous majority. Even the stories of various women's organizations and reform movements are told mainly through the life stories of their leaders. Most of the women named are pioneers, especially such as may be regarded as successful, if not in their personal lives, then at least to the extent that the changes they worked for have eventually been brought about. ${ }^{23}$ Thus more notorious figures such as Virginia Woodhull and Tennessee Chaflin are not included, while Emma Goldman is passed over quickly as "the anarchist" (p. 134).

Lerner concentrates on the more distant past, but includes a brief sketch of recent developments, concluding with the rise of the new women's movement. She distinguishes correctly between the reformist National Organization for Women and the more radical groups, while unfortunately she repeats the myth about "bra-burning." 24 Her account of feminist ideas is achievementoriented and does not refer to the anti-authoritarian attitudes of many groups. The author's evaluation of the situation of women in the United States around 1970 are positive: "The struggles of past generations have vastly improved the position of American women" (p. 145). Though she feels that "social values, mores, and institutions lag far behind the material and economic progress made" (p. 145), her epilogue stresses the gains: "The modern American woman's opportunities are limited only by her ability to take advantage of the many choices open to her" (p. 187). In Lerner's analysis this ability is largely dependent on the individual woman's strong desire. She admits, however, that the choices of black women are more limited.

It is tempting to quarrel with the selection as well as the interpretation of some of Lerner's materials, but in spite of its shortcomings, The Woman in American History contains information not to be found in standard texts. Statements which might be considered misleading, seem to be so more through the omission of information 
than through what is said directly. A certain superficiality is quite noticeable, especially in her treatment of economic matters in general and twentieth-century developments in particular. For instance, her remarks on the effects of both world wars on the employment of women are sweeping and must be qualified and supplemented by reference to other sources. ${ }^{25}$

Many aspects of Lerner's volume indicate that it is intended as a textbook at a relatively elementary level: It is brief, amply illustrated, divided into many chapters and subchapters, and the use of footnotes is limited to a minimum. Readability is an obvious pedagogical advantage, but the scanty documentation often makes it difficult to understand how the author arrived at her conclusions, thus hindering a more complete understanding of the historical process. The over-all organization of the book is chronological with thematic subdivisions within each period, but this principle of arrangement is frequently broken by the more or less "formal" biographies, which naturally tend to cross border-lines between periods and touch on various themes. What might at first sight look like a suitably simple introductory text, turns out after all to be somewhat confusing, not the least because there are no crossreferences between the different subchapters which deal with the same person or event. The bibliography is highly selective, especially with regard to working women, but it lists a number of biographies and autobiographies.

Lerner's primarily biographical approach tends to give the impression that individual efforts alone have been responsible for whatever changes have taken place throughout American history despite her initial claims to the contrary. This may be a pedagogical advantage, an efficient method of raising students' interest, ${ }^{26}$ but as history it seems little different from the old concentration on heroes. In a sense, Lerner has merely tried to "put the record straight" (p. 5) by including women. Much in the same vein, her closing comment is a glowing tribute to the traditional American dream :

The rich contribution made by women to American development and growth, to the opportunities and freedoms we prize as the "American way of life," is worth treasuring and defending. The challenges of the future are great enough to absorb the talents, creativity, and energies of all Americans-ivomen and men. (p. 190)

In The Woman in American History Lerner may be said to have substituted one bias for another. Her stress on constructive heroines 
must, however, be understood against the background of traditional history, which "has simply failed to ask those questions which would elicit information about the female contribution," as she complains in the preface to her more recent collection of sources on the history of black women. Though her concern in this book seems to be much more with the collective, she gives what amounts to a defense or justification of her approach in the earlier book:

Women as a group have been denied knowledge of their legitimate past and have been profoundly affected individually by having to see the world through male eyes. Seeing women cast only in subordinate and inferior positions throughout history and seldom, if ever, learning about female heroines or women of achievement, American girls are conditioned to limit their own life goals and selfesteem. ${ }^{27}$

Edith Hoshino Altbach does not refer to Lerner's The Woman in American History, but her own Women in America (1974) may be seen as a partial refutation of Lerner's approach. Altbach has had the advantage of writing more recently, not against the background of a predominantly male perspective: "In the few years since the women's issue became a national concern more books have probably been written about women than in the previous fifty years" (p.v). Her intention is to rectify the distortion which she finds in much of this literature and attributes primarily to the fact that

most women writing about women have forgotten or never knew what being a woman means for most women. Because of their own select background many women writers have a set of experiences alien to the lives of more unexceptional women . . . these writers may misinterpret or be entirely ignorant of the expectations and values of most women. (p.v)

Consequently, Altbach promises to deal specifically with both middle and working class housewives as well as with ordinary working women, passing more briefly over the problems of academic and professional women and single women. Her intended concentration "turns attention away from individual women in confrontation with the world or with cases of discrimination and toward the group or class experience of women coping on an everyday level, with their lives" (p. vi). Her emphasis on "the collective nature of women's situation" is apparent also in her wish to search for "the underlying grass roots sources" of feminist movements.

Given Altbach's desire to begin "a restitution to ordinary American women" (p. viii), it is surprising that roughly half of her small book is devoted to the women's movements. She does, 
however, seem to fulfil her promise to look "beyond individual feminist leaders and organizations" (p. vi). Even when she names individual leaders and pioneers, she concentrates on the causes they espoused, and does not even provide their life dates. She omits many of the individuals who figure prominently in Lerner's book, but on the other hand, she gives more information about issues and events, including dates of organizational developments, membership figures, and other statistical material, especially on the older organizations and women in the work force. Thus, although one might still find that Women in America gives disproportionately much room to organized movements, the emphasis is on the collective, not on exceptional leaders. Moreover, the discussions of women's organized efforts rest on a fairly solid foundation of facts and perspectives on the conditions of truly anonymous, ordinary women.

The primary emphasis is seen in Altbach's decision to deal first with home economics because housewives are still the majority of American women (p. 3). Her account of historical changes stresses economic, technical and demographic aspects, but also pays some attention to attitudes. In order to illustrate her view that "the management of society and the management of the home are inextricably intertwined" (p.4), she uses the vocabulary of the work world to describe the job of housework, including distinctions between white- and blue-collar tasks as well as differences between housewives according to class.

In her chapters on women at work outside the home, Altbach is concerned with tracing some of the same "system-wide economic and technical trends that lay behind the changing roles of women on the home front" (p. 41). She tries to achieve a balance between the overly optimistic and pessimistic viewpoints, at the same time warning against equating "the increasing labor force participation of women with their liberation" (p.42), and refusing to see working women solely as the victims cf social and economic discrimination. Pointing to the "deceptive quality" of much data on women, she also adds a critical perspective on sources. She deals with the various changes in women's employment patterns, the shifts from farm to factory to office, explaining how women's "active labor history cuts straight through the Victorian era. The realities of work serve as a counterbalance to the myths and cults of womanhood that preoccupied the more leisured classes of that era" (p. 61). The influence of wars and the depression on women's participation 
in the work force, as well as the relationship between women and the unions, is also traced with some detail.

Altbach's account of the new feminism seems to be based more on first-hand impressions, at least it is less thoroughly documented and contains fewer hard data than other parts of her book. She pays special attention to political issues and gives a thoughtful survey of the diversity within the movement. Her attitude is at the same time sympathetic and critical, she provides informed opinion, a good starting-point lor discussions, although one must look to other sources for further details on the chronological development, new laws, etc. Like Lerner, Altbach ends on a hopeful note, but her hopes seem to go in a different direction:

Women's renewed feminist consciousness, it can be argued, stemmed from decades of tokenism and individual struggle ... people are offered an endless series of solutions on a personal basis, alternatives that hold out rewards of security, fulfillment, and joy. When none of these work, people begin to question some of the premises upon which solutions are based. Women have begun to question what it means to be a woman in this society. (p. 160)

Women in America contains more historical information than this brief overview may have suggested. Nevertheless, it is so heavily concentrated on analysis and understanding of the present that one may be in doubt about whether to classify it as a history text at all. Unlike most traditional histories its primary principle of organization is thematic. Moreover, it starts with the present situation, only afterwards turning to the historical past to work its way slowly towards the present again. This plan is followed rather successfully in the first part on "Domestic Life," while in the second part on "The Labor Force" there are several jumps back and forth in time, with some danger of confusion in the reader's mind. The third and fourth parts, which deal with the old and the new women's movements, arc told in a more straightforward chronological manner, though there is a brief historical overview of daycare in the middle of the section on the new movement. The date chart provided in the appendix is quite detailed and goes a long way toward helping the reader in not losing sight of chronological outlines, despite a certain arbitrariness in the selection of items, ${ }^{28}$

The many footnotes and the bibliography may also serve to open up new areas of study to the previously uninformed, just as the primary concern with the present, seen in a historical perspective, may help to raise students' interest in history as a discipline. To a large extent, then, one might say that the author has carried 
through her intention of providing a "general introduction to the history of American women" (p. vii). Clearly, it will be especially useful as a minimum background for discussions of current social and economic problems as well as of women's movements old and new, though historians may object to Altbach's mixture of past and present.

The most recent of the books under consideration is Mary P. Ryan's Womanhood in America: From Colonial Times to the Present (1975). As the title indicates, Ryan's aim is not to provide a complete history of women in America, but rather "to describe the making of the social and cultural category, womanhood, the artificial mold into which history has persistently shaped the female sex" (p. 3). She takes her cue from the Norwegian Harriet Holter's idea of sex as a basic principle of social distribution (of political authority, economic power, prestige, rewards, etc.). Therefore, her central concern is not so much with womanhood as a concept, as with "the system that creates the category womanhood and the social and cultural legacy of the girl child" (p. 5). Furthermore, the term "is meant to convey the special handicaps with which women enter history" (p. 10).

Ryan does not advance ready-made causal explanations for the particular American manifestations of these seemingly universal problems :

The American system of social distribution by sex is so intertwined with the totality of the nation's history and so fundamental to the social organization that its "causes" cannot be finely isolated. At best, the historian can trace and put in order the evolution of American womanhood and draw attention to the general societal conditions that made a particular set of sex types gel and cohere at a given time. (p. 11)

The numerous and changing images and roles of women in America can thus be seen to fall into "a coherent historical pattern, taking a shape consonant with broad stages of American dev'elopment" (p. 11). Ryan attempts to trace this pattern and establish connections between what she identifies as three distinct "systems of adjusting society and sex roles" and the corresponding images of womanhood. She is aware that she is dealing with "historical constructions" which cannot be said to account for every woman's life, nor to have influenced all women in the same way regardless of ethnic, racial and regional differences. ${ }^{29}$ She makes no claim to be able to offer "a microscopic analysis of the myriad complexities of woman's situation in past time," but advises us to read her book 
"in a speculative and tentative tone," believing that her judgments require "correction and elaboration" from other scholars (p. 17).

Ryan deals first with the material conditions of each period, sketching the basic characteristics of economic production and reproduction with some attention to demographic considerations. Her discussions of the various functions of women include the concrete aspects of work and childbearing as well as the pertinent legal rules and religious views. Something is said of rebellious and exceptional women, but only after the lot of the majority has been described and prevailing attitudes established, thus putting the unusual in a proper perspective. Despite her concern with the common category of womanhood, Ryan considers the particular problems of women in different circumstances.

This approach is demanding and seems to succeed best with regard to the earlier periods, as the author is probably aware of when she says that the twentieth century "eludes simple typologies" and presents chronological difficulties (p. 14). Her use of the Biblical "Adam's Rib" to symbolize womanhood in the colonial era, is meant to imply the 'coexistence of woman's central economic and social function' in agrarian society "with her constant subordination to the patriarchal male" (p. 13), and must not be misconstrued as a denial of the vital role colonial women played. The transition between agrarian and industrial economies is characterized by "a chaotic array of alternatives," while the second major construction, "Mother of Civilization," belongs to the nineteenth century industrial society, where woman is no longer seen as primarily concerned with economic production (which"the new order dictated" be removed from the household unit), but with "nurturance, first of the individual families and through them of all America" (p. 13). The term "Social Housekeeper," which is used in the discussion of the period 1860-1920, may be seen as a natural extension of this nurturing function.

The problems Ryan encounters in trying to characterize the twentieth century are turned to advantage in providing the imagery for a new label, that of the Kaleidoscope, whose fragments are jarred "from one configuration of roles and images to another" (p. 14). Though much is made of woman's role as a consumer, the new symbol of womanhood is said to be the "Sexy Saleslady," but it is above all the variety of female roles which is stressed. The reader may tend to lose sight of the overall framework in Ryan's lengthy considerations of the kaleidoscopic qualities of our own century. 
Nevertheless, the types of materials and the aspects included, may all be said to have some relevance, not only to the author's central concerns but to a study of American civilization in its broadest conception. For instance, the many references to the Ladies Home Journal, throughout the period of its roughly one hundred years of publication, illuminate the role of the mass media as well as the changing attitudes to women. Similarly, Ryan's comments on Sylvia Plath may throw some light on the individual poet, illustrate the problems of exceptional women, and help characterize a particular period in recent American history (pp. 258-260).

Womanhood in America is brought up to the time of writing, including Watergate as well as discussions within the new movement into 1974. Among the numerous subjects touched upon, the situation of black women gets particular attention. With regard to the revival of feminism Ryan shares Altbach's mixture of sympathy and criticism, but she gives more factual background and speaks more clearly from a leftist orientation. Her closing remarks provide a stark contrast to Lerner's rather whole-hearted acceptance of mainstream American ideals:

Concerted demands by women for equal economic rewards, beyond what the present beleaguered structure of capitalism can accommodate, pose a particularly menacing threat to the American systein at this point in time. Such pressure challenges the obstinate assumption of man's history since the days of Plymouth, that the status and comfort of each and every American is to be determined by a ferocious struggle to obtain a superior portion of the world's goods, then to be horded [sic!] within the male-headed family. The Utopian possibility that a feminist challenge car?,overtax this system of distributing wealth, with its legacy of inequality and joyless labor, must be kept alive in a multi-faceted and organized battle against the tyranny of manhood and womanhood in America. (p. 429)

Naturally, not all readers can be expected to share my own sympathy with Ryan's particular blend of socialist feminism. Nevertheless, her ample documentation, the way in which she uses facts to arrive at opinions, must make it difficult to deny the validity of her major points. Personally, I find it hard to see serious faults in her method after so many initial qualifications and her own awareness of possible limitations. Moreover, Womanhood in America provides much more basic, factual information on a number of different aspects than one is led to expect. In a sense, it must be considered a history of ideas, but it rests on a more solid foundation of economic and social data than many a study which is not particularly concerned with such abstractions as category, role, image, 
and symbol. A certain knowledge of general American history is taken for granted, some pieces of what must be understood as factual information are thrown forward without detailed reference, but on the whole, Ryan seems to be very thorough in the gradual development of her argument, carefully quoting and documenting as she goes along. She employs what she herself considers a "hybrid of social and cultural history" (p. 12), relying on a mixture of source materials ranging from sermons, letters, and diaries, to data on fertility rates and women's employment, and including reference to numerous other secondary studies.

My main objections against Ryan's book are mundane. The lack of a bibliography is an irritating practical obstacle to further study, though it is partially offset by the nearly thirty pages of footnote documentation and an unusually detailed index. Ryan has divided her study into seven chapters with titles bearing on the chronological development and the corresponding images of womanhood, but the volume is still felt to be rather compact as the author passes from one group of women to another, from problems of economy to popular literature without the use of subtitles. This refusal to compartmentalize may be a natural consequence of Ryan's whole approach, her wish to breed a hybrid rather than to cultivate pure strains. Moreover, her study is not an elementary introduction guided by concerns with simple readability, but a challenging contribution at a more advanced level. In my opinion she has succeeded in providing "a framework in which to explore the making of American womanhood whose bold outline is instructive and provocative" (p. 17).

Womanhood in America may serve a double function, as a thoughtprovoker for further work in women's history, and as a useful background volume for the study of American literature with particular reference to images of women, female authors, and the relationship between fiction and social reality.

In spite of certain shared concerns, these three studies are obviously rather different, not only in scope and style, but in their definitions and approaches. Such differences may in part be attributed to the authors' attitudes to the complex question of women's position in society today as well as to their hopes for the future. Women's liberation is a political issue; no wonder then that there are as many explanations and suggested solutions as there are different political attitudes in general.

To some extent these accounts of the history $\mathbf{f}$ women in 
America might also be seen as representative of different stages in a development, roughly corresponding to the shifting trends in other fields of study and in the women's movement itself. Lerner's emphasis on exceptional women might be considered a continuation of the old feminist tendency to show that women can do anything a man can do, but also fills a demand often raised by the new movement in providing "positive role models" and inspiration for further achievement. Altbach's primary concern with "ordinary women" is typical of the new stress on the collective and the anonymous, to some extent even of the tendency to restitute, if not glorify, the common female experience. This approach, too, may encourage greater self-confidence in women, but on different premises. Ryan's familiarity with certain Marxist concepts perhaps tends to make her work somewhat atypical, yet she deals with precisely the two topics singled out by Barbara Sicherman in the conclusion of her review of recent developments: gender groups in history and women's complex experience, ${ }^{30}$ both of which are necessary to a more complete understanding of the historical process. Clearly, much remains before more nearly perfect synthetic works can be expected, but the new trends seem promising.

Women's history is an exciting field, yielding new results all the time, including attempts to deal with areas of human experience previously not considered part of the historian's task, such as the personal relations between women. ${ }^{31}$ A future integration into general American history may occur according to the pattern suggested for black history by Aileen S. Kraditor, moving through a stage of specialization until "the enormous gaps in our knowledge begin to narrow," and scholars recognize the integral role of a neglected group..$^{32}$

Such an integration in subject matter does not, however, necessarily mean that the female perspective will disappear entirely, in historian Linda Gordon's view:

We must show that the female experience is as much the human experience as the male. In arguing that women's studies should put women at the center, I am arguing against the notion that we should focus exclusively on women. On the contrary, by looking at the human experience from the point of view of women:, we can understand the male experience and the whole culture much better. ${ }^{33}$ 


\section{NOTES}

1 Gerda Lerner, The Woman in American History, Specialized Studies in American History Series (Reading, Mass.: Addison-Wesley, 1971), 190 pp.-bibliography $10 \mathrm{pp}$; Edith Hoshino Altbach, Women in America (Lexington Mass.: D.C. Heath and Company, 1974), X+160 pp. +appendix 32 pp. +bibliography 8 pp; Mary P. Ryan, Womanhood in America: From Colonial Times to the Present (New York: Franklin Watts, Inc., New Viewpoints, 1975), 429 pp. + notes $30 \mathrm{pp}$. References to these books will be given in parentheses.

2 See Catharine R. Stimpson, "What Matter Mind: A Theory About the Practice of Women's Studies," Women's Studies: An Interdisciplinary Journal, 1 (1973), 293-314; Drude Dahlerup, "Betragtninger over de nye kvindestudiers baggrund, indhold og perspektiv," Politica: Tidsskrift for politisk videnskab, 7, Nos. 2-3 (1974), 2-53; and Cheri Register, "Women's Studies in the United States," to be published in Image ,3, No. 2 (1976). Further bibliographical information may be found in the quarterly Women's Studies Abstracts (1972-) and in Women's Work and Women's Studies (1971-). In addition to the Women's Studies journal (1973-) the most useful among the new ventures seem to be Feminist Studies (1973-) and Signs: Journal of Women in Culture and Society (1975-).

3 The complete text may be found in Image, Myth and Beyond: American Women and American Studies, vol. 2, ed. Betty E. Chmaj (Pittsburgh, Pa.: KNOW, Inc., 1972), pp. 77-78. Italics added.

4 AQ, 27 (August 1975), see especially 314 and 321. A good bibliographical survey is Joanna Schneider Zangrando, "Women's Studies in the United States: Approaching Reality," American Studies International, 14, No. 1 (Autumn 1975), 15-36.

5 U.S. News \& World Report, December 8, 1975, p 56. The proportion is expected to increase in the future.

6 For instance, Dennis Welland, editor of The United States: A Companion to American Studies (London: Methuen \& Co Ltd, 1974), states as an important purpose of his volume: "to open up lines of inquiry and point in the direction of further study" (p. 7), an admirable goal for a textbook. Unfortunately, Women's Studies is not included among the directions in which Welland wants to point, see my critique "The Invisible Majority (or, the Parenthetical Afterthought)," to be published in Image, 4, No. 1 (1977).

7 Women's Studies, 2 (1974), 105-113, here 105.

8 Lois W. Banner, "On Writing Women's History," The Journal of Interdisciplinary History, 2 (1971), 347-358, here 351. See also Gerda Lerner, "New Approaches to the Study of Women in American History," Journal of Social History, 3, No. 1 (1969-70), 53-62, on Beard's contributions especially 54-55.

9 Miller, 110.

10 For instance, a search for twelve selected titles (all from the period 1962-72), which appear again and again in American articles on women's history, showed that only two of the books (from 1964 and 1972) had reached Norwegian libraries by December 1975. The situation may be somewhat better in Sweden and Denmark, due to the earlier establishment of special archives and catalogues of Women's Studies, thus the journal Women's Studies has been available in Denmark from the start of publication, but not in Norway. The recent creation of a documentation service at the University Library in Bergen is a hopeful sign.

11 Mary Beard, Woman As Force in History: A Study in Traditions and Reality (New York: Macmillan, 1946; Collier ed., 1962), "Preface" [p. 10]. 
12 Carl N. Degler, Is There a History of Women? An Inaugural Lecture delivered before the University of Oxford on 14 March 1974 (Oxford: Clarendon, 1975), p. 5.

13 Lerner, "New Approaches," 53. Cf. Ruth Rosen, "Sexism in History or, Writing Women's History Is a Tricky Business," Journal of Marriage and the Family, 33 (1971), 541-544, especially 541: "History has been the record of those who controlled other people's lives."

14 The American Mind: An Interpretation of Thought and Character Since the 1880's (New Haven \& London: Yale University Press, 1950), p. 36. This is not to say that Commager says much about women's struggle.

15 Miller, 107, speaks of "the danger of becoming enmeshed in the suffrage movement to the exclusion of far more important problems."

16 This, roughly, is the definition preferred by Ida Blom in "Kvinnehistorie som forskningsområde," Forskningsnytt, 21, No. 1 (1976), 8-13.

17 According to Zangrando (note 4), 22, "The most predominant theme of specific histories on women in the United States has been the organized struggle for women's rights, particularly suffrage, from the 1840s to 1920." For a critique of this predominance and other limited types of women's history, see Ann D. Gordon, Mari Jo Buhle and Nancy E. Schrom, "Women in American Society: An Historical Contribution," Radical America, 5, No. 4 (1971). Several of the most frequently cited studies have been charged with sexist bias, see Rosen (note 13) and Linda Gordon and al., "A Review of Sexism in American Historical Writing," Women's Studies, 1 (1972), 133-158.

18 William H. Chafe, The American Woman: Her Changing Social, Economic, and Political Roles, 1920-1970 (New York: Oxford University Press, 1972), p. ix. Cf. Barbara Sicherman, "Review Essay: American History," Signs, 1, No. 2 (Winter 1975), 461-485, especially 462: "There is currently no consensus on an appropriate conceptual framework for women's history."

19 Roger Thompson, Women in Stuart England and America (London \& Boston: Routledge \& Kegan Paul, 1974), p. 263.

20 Joan Hoff Wilson, 'Woman As a Declining Force in American History," paper delivered at a regional ASA meeting, California, 1971, published in Chmaj, ed., pp 224-238 (note 3).

21 Readers interested in special topics or limited periods only will find a useful guide in Sichernian (note 18), including comments on articles.

22 Edward T. James and al., eds., Notable American Women, 1607-1950: A Biographical Dictionary (Cambridge, Mass.: Harvard University Press, 1972), 3 vols, accounts for 1359 names!

23 Lerner's defense: "While it is true that the vast majority of women were unaffected by all these activities and continued to be concerned mainly with domestic affairs, the changes the reformers helped to bring about in the social structure ultimately affected all women and society as a whole" (pp. 130-131).

24 Lerner, p. 185. According to Jo Freeman, The Politics of Women's Liberation: A Case Study of an Emerging Social Movement and its Relation to the Policy Process (New York: David McKay, 1975), p. 112, "There has yet to be a woman in women's liberation to burn a single bra publicly, but this mythical act was widely reported in the press." Cf. Judith Hole and Ellen Levine, Rebirth of Feminism (New York: Quadrangle, 1973), pp 229-230, and Gene Marine, A Male Guide to Women's Liberation (New York: Avon, 1974), p. 193.

25 Lerner, pp. 143 and 177, cf. Chafe (note 18), pp. 51-54, 179-184. For a discussion of the post-World War II period, see my article "Apropos Betty Friedan: Kvinnebilde, konjunkturer og kvinner i arbeidslivet," KjerringRåd: Kvinnepolitisk tiásskrift, No. 6 (2/1976), 39-41. Further details on women in the work forcemay be found in Elizabeth Faulkner Baker, Technology and Woman's 
Work (New York \& London: Columbia University Press, 1964); Robert W. Smuts, Women and Work in America (New York: Columbia University Press, 1959); and Esther Peterson, "Working Women," in The Woman in America, ed. Robert Jay Lifton (Boston: Beacon Press, The Daedalus Library, 1967), pp. 144-172.

26 See Lerner's report "Teaching Women About Women," Female Studies II, Collected by the Commission on the Status of Women of the Modern Language Association, ed. Florence Howe (Pittsburgh: KNOW, Inc., 1970), pp. 86-88.

27 Gerda Lerner, Black Women in White America: A Documentary History ((New York: Pantheon, 1972), p. xvii.

28 One may for instance question the relevance of Edward VIII, Grace Kelly and Hope Cooke to Altbach's main concerns. What she believes to be the first American cookbook (1761) was actually published in London much earlier: [E. Smith,] The Compleat Housewife. (The British Museum has a copy of the third ed., 1729.) Her item (p. 170) on the first women to cross North America refers to women of European descent; cf. Nancy Wilson Ross, Westward the Women (New York: Alfred A. Knopf, 1944), pp. 93-99, on the Indian guide Sacajawea, who accompanied Lewis and Clark from North Dakota to the Pacific, 1804-06 (carrying a child on her back).

29 See pp. 12, 16 and 17, where different groups are mentioned, including those she does not propose to deal with, e.g. "native Americans" and women on the frontier. Historical accounts of Indian women seem to be few and far between. Dee Brown, The Gentle Tamers: Women of the Old West (1973), repr, as Women of the Wild West (London: Pan, 1975), refers to a number of sources on pioneer women, but says little on female Indians. Walter O'Meara, Daughters of the Country: The Women of the Fur Traders and Mountain Men (New York: Harcourt Brace Jovanovich, 1959) includes more, see extracts entitled "American Indian Women," in The Woman Question in American History, ed. Barbara Welter (Hinsdale, I1l.: The Dryden Press, 1973), pp. 13-21.

30 Sicherman (note 18), 484.

31 See Carroll Smith-Rosenberg, "The Female World of Love and Ritual: Relations between Women in Nineteenth-Century America," Signs, 1, No. 1 (Autumn 1975), 1-29.

32 Up From the Pedestal: Selected Writings in the History of American Feminism, ed. Aileen S. Kraditor (Chicago: Quadrangel, 1968), p. 4. Cf. Dahlerup (note 2), $19-20$.

33 Linda Gordon, "A Socialist View of Women's Studies: A Reply to the Editorial, Volume 1, Number 1," Signs, 1, No. 2 (Winter 1975), 559-566, here 563.

\section{SOME USEFUL ADDRESSES}

Dokumentasjonstjeneste for kvinnelitteratur, v/bibliotekar Inger Johnsen, Universitetsbiblioteket i Bergen, 5000 Bergen, Norway.

Feminist Studies, 417 Riverside Drive, New York, NY 10025, USA.

KNOW, Inc., P.O. Box 86031, Pittsburgh, Pennsylvania 15221, USA.

Kvinnohistoriskt arkiv, Goteborgs Universitetsbibliotek, Renstromsg. 4, Box 5096, Goteborg 5, Sverige. 
Signs: Journal $₫$ Women in Culture and Society, The University of Chicago Press, 5801 Ellis Avenue, Chicago, Illinois 60637, USA.

Women's Studies: An Interdisciplinary Journal, Gordon and Breach Science Publishers Ltd., 42 William IV Street, London WC 2, England/1 Park Avenue, New York, NY 10016, USA.

Women's Studies Abstracts, P.O. Box 1, Rush, New York 14543, USA.

Women's Studies Newsletter, The Feminist Press, Box, 334, Old Westbury, New York 11568, USA.

Women's Work and Women's Studies, NOW, Inc. (see above), compiled by the Women's Center of Barnard College, New York, NY 10027, USA.

Siri Nylander, TDH, 3800 Bö, Norway. 